\title{
Making Work Pay in Slovenia
}

\author{
SUZANA LAPORŠEK* \\ MILAN VODOPIVEC \\ MATIJA VODOPIVEC
}

Faculty of Management Koper
Review paper

UDK: 331.2(497.4)

doi: $10.3935 /$ rsp.v26i3.1582

Received: August 2018

University of Primorska

Koper, Slovenia

The paper analyzes incentives for making transition from non-employment to work as expressed by various financial indicators in Slovenia and compares them to the EU countries. It also provides an overview of the main features of making-work-pay policies and discusses reasoning for their implementation in Slovenia. The paper shows that in Slovenia, families and individuals who are not working have poor incentives to find a job-because for many, "it does not pay to work." Unemployment benefits and cash transfers, coupled with high tax wedge, create high work disincentives. To address this issue, Slovenia should consider introducing into-work benefits, in-work benefits, or both. Presently such policies are virtually non-existent. In the light of international successful experiences with such policies and given the strong work disincentive created by unemployment, inactivity and low-pay traps, in Slovenia such policies have a great potential to stimulate transitions from non-employment to employment and stay in employment.

Keywords: making work pay, in-work benefits, into work benefits, unemployment trap, inactivity trap, low wage trap, Slovenia.

\section{INTRODUCTION}

Unemployment benefits and cash transfers may create work disincentives, especially when coupled with large taxation rates of personal income. Particularly for families with several dependents, such circumstances can create an "unemployment trap" or an "inactivity trap" - disincentives due to non-employment benefits being relatively high compared with expected incomes when working, as well as the "lowwage trap" - disincentives due to additional taxes and of cash benefit reductions taking away most of additional earnings from increased hours worked. An important factor is also a tax burden on labor. There is compelling empirical evidence that high taxes on labor, especially in combination with unemployment benefits, significantly increase unemployment (OECD, 2004; for an overview of studies on the effects of tax wedge see also Dolenc and Laporšek, 2010).

As taxes and benefits have negative effects on individual's work decision, it has become important to regularly assess financial incentives to work, among which the most commonly used ones are the marginal effective tax rates - i.e., the unemployment trap, the inactivity trap and the low wage or poverty trap. Their magnitude (i.e., percentage of additional earnings being lost due to increasing taxes and decreasing benefits)

\footnotetext{
* Suzana Laporšek, Faculty of Management Koper, University of Primorska / Fakulteta za management Koper, Univerza na Primorskem, Cankarjeva 5, 6000 Koper, Slovenia / Slovenija, suzana.laporsek@fm-kp.si
} 
may affect structural unemployment, decision to stay in employment and working hours, especially for low-productivity and low-paid workers. Identifying financial incentives to work is therefore an important guide for shaping making-work-pay policies and reforms of tax and welfare systems (Carone et al., 2004).

To improve low-pay earners' incentives to participate in the labor market and to reduce poverty of marginal groups of workers and their dependents, several OECD/EU countries have introduced policies aimed at making work pay. These policies have two main objectives: (i) increasing employment by creating additional financial rewards for remaining in employment or for accepting (a low-paid) job, and (ii) enhancing the incomes of disadvantaged groups of workers and their families (Immervoll and Pearson, 2009). Countries may also have specific objectives adapted to their economic and institutional circumstances - for example, in some of the EU countries with generous social transfers (for example, Sweden, Finland, France, Belgium and Germany), making-work-pay policies have been introduced to ensure that there is a financial difference between welfare and paid work (Bargain, 2008).

Making-work-pay policies are typically targeted at people who face the highest risk of unemployment and poverty in work. As such, they are especially attuned to situations when people are receiving only out-ofwork incomes, have low earnings capacity, or work in low paid jobs (Bargain et al., 2010). Yet the decision to take up a job is not influenced only by financial, but also by non-financial factors, such as availability of childcare, balance between work and family life, working conditions, and training and rehabilitation. Although this paper focuses only on financial incentives, non-financial factors must also be considered when designing policies aimed at enhancing labor market participation, especially of women, lone parents and older workers (EMCO, 2003).

The paper firstly describes main features of making-work-pay policies, supported by examples of the EU and the OECD countries. In empirical part it aims to analyze work incentives indicators in Slovenia and to put Slovenia in the international perspective. The paper also discusses whether Slovenia should, following international experience, introduce making-work-pay policies. While existing programs cannot simply be transplanted to other countries, much can be learned from their experience.

The organization of the paper is as follows. We first provide an overview of international experience with making-work-pay policies (Section 2). We continue with the analysis of work incentives indicators in Slovenia and the EU countries (Sections 3 and 4). The final section summarizes main findings and discusses the sense of introducing into-work benefits, in-work benefits, or both in Slovenia.

\section{OVERVIEW OF MAKING- WORK-PAY POLICIES IN THE OECD/EU COUNTRIES}

Making-work-pay policies take two forms: (i) into-work benefits and (ii) permanent in-work benefits, which can be further grouped into tax credits and reductions of personal income taxes and/or of employee social security contributions. ${ }^{1}$ An overview of implementation of making-workpay policies across OECD/EU countries shows that into-work benefits can be found

\footnotetext{
${ }^{1}$ These policy measures address the labor supply side, as they incentivize individuals by increasing their work incomes. Another strand of making-work-pay policies, which are not explicitly addressed in this paper, focuses on labor demand and aims at reducing labor costs of hiring (low-skilled) workers via employer-based approaches.
} 
in nine $\mathrm{OECD} / \mathrm{EU}$ countries, ${ }^{2}$ whereas inwork benefits have been implemented in twelve OECD/EU countries. ${ }^{3}$ Into-work and in-work benefit schemes differ in several aspects, but they all have in common that eligibility is contingent on paid employment. Below we describe key features of both schemes.

Into-work benefits typically provide support for a few months after the start of new employment or take the form of one-off payment. Due to this, they have a limited effect on reducing in-work poverty (Immervoll and Pearson, 2009). However, the time limitation may strengthen incentives, as it may encourage recipients to progress more rapidly in their jobs to achieve self-sufficiency (OECD, 2003). In most countries into-work benefits depend on the recipient's prior status, rather than just being income-tested. They are mostly targeted to unemployed, particularly long-term unemployed, workers receiving unemployment benefits or social assistance (Canada, Germany, Ireland, Japan, Korea and Romania) and can therefore be received by a smaller number of people. Eligibility for these benefits may be contingent on additional characteristics of the recipient. ${ }^{4}$ The generosity of these benefits varies across countries from 180 EUR (253 CAD) paid as a lump sum once a year in Canada to 950 EUR per month for up to a year in Austria. In Japan, Korea and Romania the amount of benefit is linked to the amount of unpaid "remaining unemployment benefit" at the start of a job (OECD, 2018a).

In-work benefits are targeted to low-income individuals or families with at least one family member employed. As the amount of benefits is in most cases linked to income from work and/or hours worked, this group of benefits has a more pronounced effect on income distribution and in-work poverty and, in addition, stimulates workers to remain in employment (Immervoll and Pearson, 2009). Most in-work benefits are not time limited. ${ }^{5}$

Most OECD/EU countries apply inwork benefits in a form of tax credits. Tax credits are mostly targeted to individuals or families with children, with the aim of topping-up low wages (for example, the Working Income Tax Benefit in Canada, the Earned Income Tax Credit in Korea, Sweden and the United States, and the Working Tax Credit, formerly Working Families Tax Credit, in the United Kingdom). The eligibility and the amount of tax credit is determined based on income from work, working hours, and the number of children, often by a combination of the three criteria. Reflecting the fact that they represent a tool for in-work benefits and child poverty reduction, in several countries in-work benefits are directed only to working families with children (for example, Ireland, South Korea, New Zealand; see Immervoll and

\footnotetext{
${ }^{2}$ Austria, Belgium, Canada, Germany, Ireland, Japan, South Korea, Romania and Slovakia. A detailed description of into-work benefits in these countries is available at OECD (2018a).

${ }^{3}$ Canada, Chile, France, Ireland, South Korea, the Netherlands, New Zealand, Sweden, the United Kingdom, the United States. Belgium and Finland apply in-work benefits in a form of reduction in personal income tax and/or employee social security contributions. A detailed description of permanent in-work benefits in these countries is available at OECD (2018a).

${ }^{4}$ For example, in Austria, into-work benefits are available to workers who are unemployed for six months or more and are older than 45 years; or returning to work from parental leave; or being of low work capacity. In Slovakia into-work benefits are provided to long-term unemployed who earn less than double the minimum wage (see Gerbery, 2015), whereas in Belgium to long-term unemployed lone parents (OECD, 2018a).

5 An exception to this is Ireland, where the in-work benefit lasts for one year, however it is renewed conditional that the person remains in employment (OECD, 2018a).
} 
Pearson, 2009; Immervoll, 2016). ${ }^{6}$ In contrast, in Finland, France and Sweden tax credits are calculated based only on an individual's earnings, implying that their main aim is the promotion of work-incentive and not so much a type of redistribution (OECD, 2003, 2005). Compared to family-based schemes, individual-based in-work benefits are likely to have greater incentive effects for all earners, because such schemes have smaller discouraging effects on second earners in couples (Bargain, 2008). However, this might come at the expense of higher costs and poorer targeting, as low earners in non-poor households may also become eligible (Matsaganis and Figari, 2016). The generosity of tax credits varies significantly across countries. As regards the compensation design, most countries have a phase-in region, followed by a plateau and a phase-out region (van der Linden, 2016). The phase-in and phase-out rules, beside benefit level, define the level of benefit generosity. The in-work benefits are most generous in the United Kingdom, whereas the United States record one of the lowest in-work benefit generosities. ${ }^{7}$

Tax credits schemes are perceived as costly and administratively demanding schemes. Estimations show that the budgetary costs for tax credit system present up to 2 percent of GDP in the United Kingdom and 1.3 percent of GDP in Australia, while in the United States they amount to about 0.6 percent (OECD, 2014). Besides, they are often criticized for being bureaucratic and non-adaptive to changes in family or individual situations, what led to reforms of the system in, for example, France and the United Kingdom.
The second type of in-work benefits, the reduction in personal income tax and/ or employee social security contributions, aims to increase the net earnings of lowwage workers so as to keep them in employment. In both Belgium and Germany, this policy has been introduced as a part of a more comprehensive tax reform aimed at decreasing the negative effects of a high tax burden on employment (see OECD, 2003).

\section{INSTITUTIONAL BACKGROUND IN SLOVENIA: UNEMPLOYMENT INSURANCE, SOCIAL ASSISTANCE AND FAMILY BENEFITS}

In line with other EU countries, Slovenia provides a comprehensive social protection system. For unemployed workers, there is an unemployment insurance program offering financial support, as well as a range of active labor market programs. In addition, the registered unemployed are also provided coverage under the mandatory health insurance. Moreover, social assistance, a means-tested financial assistance, is also available to individuals and families with insufficient means for living. Families with children and low incomes are also eligible for child allowance. ${ }^{8}$

Unemployment insurance works as follows. Unemployed workers can claim unemployment benefits after termination of fixed-term employment or after involuntary termination of employment under the permanent contract. To qualify for unemployment benefits, workers must have been employed for at least nine months in the preceding 24 months (for young workers under the age of

\footnotetext{
${ }^{6}$ Child-related eligibility conditions are observed especially in countries where in-work benefits have a strong redistributive role (Immervoll and Pearson, 2009).

${ }^{7}$ For example, in the United Kingdom there is no phase-in, whereas phase-out is set at 41 percent of average wage (see OECD, 2005, 2018a). In contrast, in the United States the phase out rates for lone parents with two children is about 20 percent and for single workers about 8 percent of average wage (Edwards and de Rugy, 2015).

${ }^{8}$ There are also other social assistance programs in Slovenia, however, we do not include them in this paper, as they do not directly relate to the making-work-pay policies.
} 
30 , six months in the preceding 24 months). The potential benefit duration is determined by the cumulative duration of employment engagements preceding the onset of unemployment and the age of unemployed person. The benefits range from two months for young workers with six to eight months of prior employment to a maximum of 25 months for workers aged 55 or more (see Table 1). In addition, the Employment Service of Slovenia (ESS, 2018) pays pension and invalidity insurance contributions for a maximum of one year for the unemployed close to retirement (i.e., 57 years of age or having 35 years of paid contributions). Entering retirement via unemployment insurance system is therefore quite common in Slovenia, as about 30 percent of all old-age pension recipients entered retirement in this way (OECD, 2016). ${ }^{9}$

Table 1

Potential duration of unemployment benefits in Slovenia, 2019

\begin{tabular}{lc}
\hline $\begin{array}{l}\text { Length of prior } \\
\text { unemployment insurance }\end{array}$ & $\begin{array}{c}\text { Potential benefit } \\
\text { duration } \\
\text { (in months) }\end{array}$ \\
\hline $6-8$ months (age below 30) & 2 \\
\hline 9 months -5 years & 3 \\
\hline $5-15$ years & 6 \\
\hline $15-25$ years & 9 \\
\hline over 25 years & 12 \\
\hline $\begin{array}{l}\text { over 25 years and aged 50- } \\
54 \text { years }\end{array}$ & 19 \\
\hline $\begin{array}{l}\text { over 25 years and aged 55+ } \\
\text { years }\end{array}$ & 25 \\
\hline
\end{tabular}

Source: Labour Market Regulation Act, 2013. Official Gazette of the Republic of Slovenia, No. 80/10, 21/13, 63/13, 100/13.
The level of unemployment benefit, determined by a statutory replacement rate, is diminishing in time. The level of monthly benefits is calculated based on the average monthly wage received during the last eight months (or five months for young workers) prior to the onset of unemployment. The amount of a monthly benefit is determined as a share of so-determined average wage, that is, by the replacement rate. This rate is set at 80 percent for the first three months of the unemployment spell, and it is reduced to 60 percent between the fourth and the twelfth month of unemployment, and to 50 percent thereafter. The benefit paid is subject to an absolute minimum of 350 EUR gross and maximum of 892.50 EUR gross (Labour Market Regulation Act, 2013).

Those who do not qualify for unemployment benefits may be eligible for social assistance. Financial social assistance in Slovenia is a means-tested cash transfer provided to individuals with no income or income below the statutory set basic minimum income (i.e., 392.75 EUR since January 1,2019$).{ }^{10}$ The eligibility criteria include possessing assets that enable subsistence, taking advantage of other cash transfer schemes, and engaging in finding solutions to become financially independent (for example, actively seeking employment if unemployed). In case of no income, individuals without children receive the full basic minimum income; otherwise, they are entitled to the difference between their own income and the basic minimum income. The amount of cash financial assistance to a family is determined as the difference

\footnotetext{
${ }^{9}$ Compared to the OECD countries, Slovenia stands out with the long potential benefit duration for older workers. In about half of the European OECD countries, potential benefit duration is limited to one year (or less), regardless the age of the unemployed (see OECD (2016) for details).

${ }^{10}$ In June 1, 2018, the statutory set basic minimum income increased for 29 percent (from 297.53 EUR to 385.05 EUR) on the proposal of a political party The Left (sl. Levica). Due to the adjustment with inflation, the basic minimum income amounts 392.75 EUR since August 1,2018. Although it was intended that the statutory minimum income will be decreased in January 2019 to 331.26 EUR, the new Government kept the minimum income at the same level.
} 
between the sum of minimum incomes to which individual family members are entitled, and the incomes of all family members (Ministry of Labour, Family, Social Affairs and Equal Opportunities of the Republic of Slovenia, 2019).

Financial social assistance is time limited and subject to renewal, but in some cases may also be permanent. Initially, financial social assistance is granted for a period of three months, and it can be extended to a maximum period of six months or one year if the improvement in the social position cannot be expected (due to age, illness or disability). In case of permanent incapability for work or old-age (above 63 years for women and 65 years for men), individuals can be granted permanent financial social assistance (if they are not eligible for disability pensions). Individuals receiving financial social assistance may also qualify for exceptional financial social assistance, which is granted in exceptional circumstances to cover extraordinary or urgent expenses or in cases when individual is found in financial distress for reasons beyond his/her control. It is paid as a lump sum or for a duration of three to six months, in the monthly amount up to 392.75 EUR for an individual and up to 1,080.06 EUR for a family with two children. Individuals can also apply for supplementary allowance in case of permanent incapacity and for coverage of the additional cost of care. Families with children are also eligible to means-tested child allowance (Ministry of Labour, Family, Social Affairs and Equal Opportunities of the Republic of Slovenia, 2019).

Recipients of financial social assistance are also eligible for an activity allowance, aimed to encourage employment or motivation for work. To be eligible, an individual must be employed or engaged in volunteer work. The level of monthly activity allowance depends on the number of hours worked and it ranges from 102.12 EUR for individuals working 60 to 128 hours per month to 200.3 EUR for individuals working more than 128 hours per month (Ministry of Labour, Family, Social Affairs and Equal Opportunities of the Republic of Slovenia, 2019).

Families with low-incomes and children are eligible for child allowance, which is a supplementary monthly benefit for maintenance, care and education of children. The level of child allowance is determined with regard to the classification of the family into individual income classes. Families with four or more children are also eligible for a large family allowance supplement, which takes the form of a yearly one-off benefit (Ministry of Labour, Family, Social Affairs and Equal Opportunities of the Republic of Slovenia, 2019).

\section{DOES IT PAY TO WORK? SLOVENIA IN AN INTERNATIONAL PERSPECTIVE}

Below we analyze work incentive indicators for Slovenia and compare them to the EU countries.

\section{Methodology and Data}

When taking up a job or increasing working hours, a significant part of new earnings can be taxed away through higher income taxes or reduced benefits. For some individuals or families this can result in little or no gain from being employed in a lowpaid job or working more hours (OECD, 2018b). To estimate the effect of tax and benefits system on the incentives to work, we examine several commonly-used measures. The most important is the marginal effective tax rate (METR), which measures what part of any additional earnings is taxed away through the combined effect of increasing taxes and decreasing benefits (OECD, 2018c). It is computed as: 


$$
M E T R=1-\frac{\Delta y_{\text {net }}}{\Delta y_{\text {gross }}}
$$

where $\Delta y_{\text {gross }}$ are the additional earnings and $\Delta y_{n e t}$ is the change in net income obtained after taxes and benefits. The change in gross earnings between labor market states $\mathrm{A}$ and $\mathrm{B}$ is:

$$
\Delta y_{\text {gross }}=y_{\text {gross } B}-y_{\text {gross } A}
$$

and the change in net income is:

$$
\begin{gathered}
\Delta y_{\text {net }}=y_{\text {net } B}-y_{\text {netA }}=\left(y_{\text {gross } B}-t_{B}+b_{B}\right)- \\
\left(y_{\text {gross } A}-t_{A}+b_{A}\right)
\end{gathered}
$$

where $t$ denotes total taxes and $b$ denotes total benefits (OECD, 2018c).

The METR for a transition into work from non-employment is called the participation tax rate (PTR). Its definition is equivalent to METR with labor market state B being "in work" (IW) and labor market state A being "out of work" (OW) (OECD, 2018c):

$$
\text { PTR }=1-\frac{\Delta y_{\text {net }}}{\Delta y_{\text {gross }}}=1-\frac{y_{\text {net } I W}-y_{\text {netow }}}{y_{\text {gross } I}-y_{\text {grossow }}}
$$

We will use the following work incentives measures (Carone et al., 2004; European Commission, 2015; OECD, 2018c):

- PTR for recipients of unemployment benefits (i.e., unemployment trap) as an indicator for transitions from unemployment to employment - it measures the part of the additional gross wage that is taxed away in the form of increased tax- es and withdrawn benefits such as unemployment benefits, social assistance, and housing benefits when a person returns to work from unemployment. ${ }^{11}$

- PTR for recipients of safety-net benefits (i.e., inactivity trap) as an indicator for a transition into work from inactivity without unemployment benefits - it measures the part of additional gross wage that is taxed away in the case where an inactive person (not entitled to receive unemployment benefits but eligible for income-tested social assistance) takes up a job.

- METR for part-time workers (i.e., lowwage or poverty trap) as an indicator of increasing working hours or work effort - it is defined as the rate at which taxes are increased and benefits withdrawn as earnings rise. This trap is most likely to occur at relatively low wage levels due to the fact that the withdrawal of social transfers, which are usually available only to persons with a low income, adds to the marginal rate of income taxes and social security contributions.

The data for the analysis were obtained from the European Commission's database Tax and benefits database (2018), OECD statistical database (OECD.Stat, 2018) and the OECD Tax and Benefits database (OECD, 2018d).

\section{Unemployment Trap}

The financial incentives to move to employment from unemployment while receiv-

${ }^{11}$ PTR for unemployment benefits is closely related to the commonly-used measure net replacement rate (NRR) measure (defined as a ratio of net income while out of work divided by net income while in work), yet the relationship is not straightforward. The difference between the two measures is in the effect of earnings received by other household members. Namely, the NRR takes into the account also incomes of other household members (they are included both in a numerator and denominator). This implies that, particularly in the case of two-earner families, the NRR can be driven by the spouse's earnings. In contrast, the PTR relates the change in net household income to the change in gross earnings and is therefore not directly affected by the level of earnings received by other household members. The PTR is therefore considered a better indicator of financial work incentives. For a single or a single earner household with no other income than earnings a high NRR implies also a high PTR (OECD, 2018c). 
ing unemployment benefits are relatively weak for low-wage earners in Slovenia. As shown in Figure 1, tax rate at the wage of 67 percent of average wage in most cases exceeds 85 percent. This implies that taking a full-time job at the 67 percent of average wage would result in 85 percent or more of the additional earnings being lost due to taxes and reduced benefits. Similarly, high unemployment traps are experienced by single persons and two-earner married couples with two children earning minimum wage. ${ }^{12}$ PTRs tend to lower with the increase of wage at employment.

Figure 1

PTR for transition into full-time employment for persons receiving unemployment benefits at the initial level (during the first three months of the receipt), Slovenia, 2016, in percent

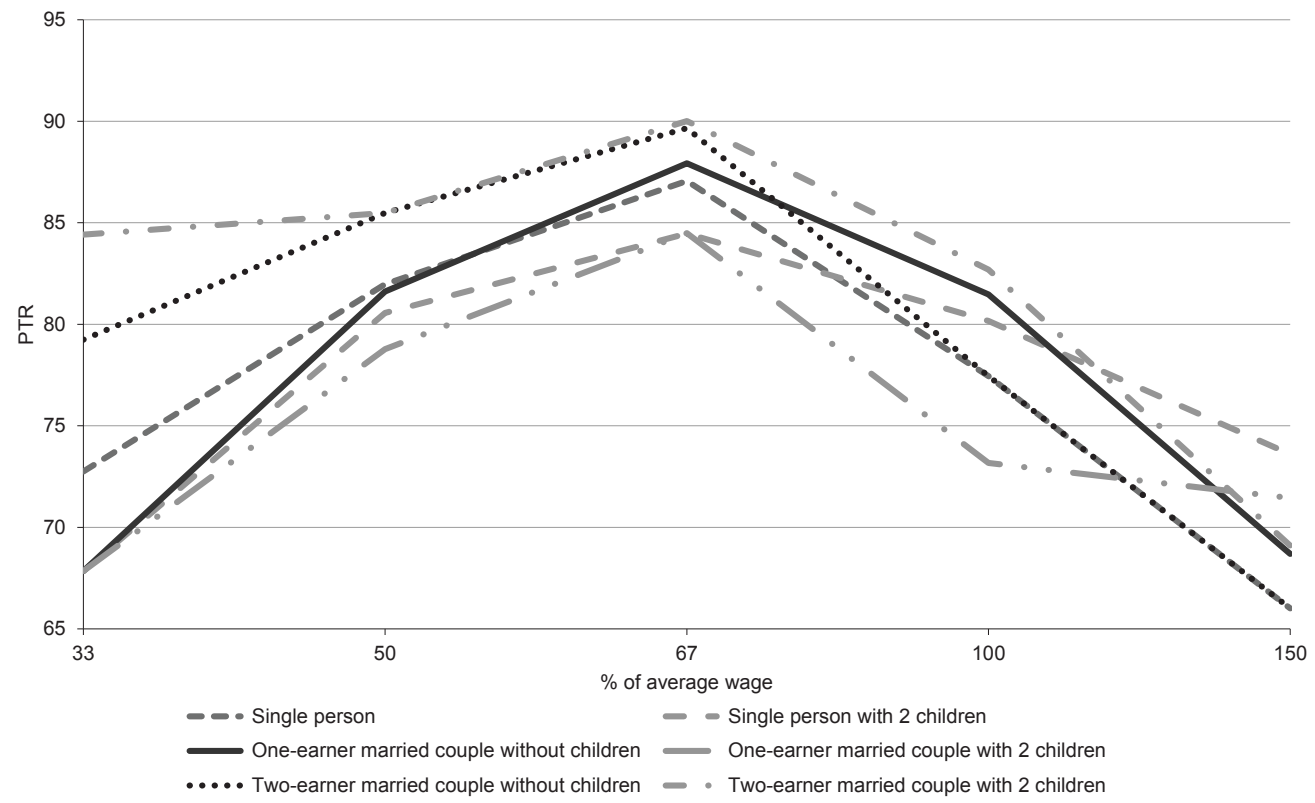

Notes: The PTR estimates relate to individuals who have just become unemployed and receive unemployment benefits. Estimates are based on the following assumptions:

- Social assistance or cash housing assistance are assumed to be available in either in-work or out of work. Any benefits payable on moving into employment are assumed to be paid.

- The percentage of average wage relates to wage in full-time employment of the individual when moving into work. For married couples, the percentage of average wage relates to one spouse only; the second spouse is assumed to be inactive with no earnings in one-earner couples and to have full-time earnings equals to 67 percent of average wage in two-earner couples.

- Estimates for families with children assume two children aged 4 and 6 and with family benefits.

Sources: European Commission, 2018; OECD, 2018d; own calculations.

\footnotetext{
${ }^{12}$ As the equivalent of a minimum wage we consider 50 percent of the average wage.
} 
Slovenia faces a relatively strong unemployment trap compared to the EU countries. As shown in Figure 2, Slovenia ranks $5^{\text {th }}$ among the EU countries by the PTR for unemployed single person with no children when employing at the 67 percent of the average wage - by employing at this wage, this single person lost 87.1 percent of the additional earnings due to taxes and reduced benefits in 2016 (the EU average was 75.8 percent). The unemployment traps for single person were higher only in Belgium, Denmark, Luxembourg and Latvia. In contrast, the most favorable results were observed in Romania and Slovakia, where PTR was below 50 percent. Slovenia is also at the very top among the EU countries with regard to unemployment traps for other family types (see
Figure 2) - it ranks $1^{\text {st }}$ among the EU countries with regard to the PTR for two-earner couples with or without children (i.e., 90 and 89.7 percent in 2016 , respectively) and $4^{\text {th }}$ with regard to the PTR for one-earner couples without children ( 87.9 percent). Overall, the EU countries record 8 to 18 percentage points lower average value of the PTR across different family types at the 67 percent of the average wage than Slovenia. ${ }^{13}$ Transitions from unemployment to employment are most favorable in Slovakia and Romania, especially for lone parents and one-earner couples. For two-earner couples, the lowest PTR is observed in the United Kingdom and Malta (see European Commission, 2018). All these countries, with the exception of Malta, provide in- or into-work benefits.

Figure 2

PTR for transition into full-time employment at 67 percent of average wage for persons receiving unemployment benefits at the initial level (during the first three months of the receipt), the EU countries, 2016, in percent

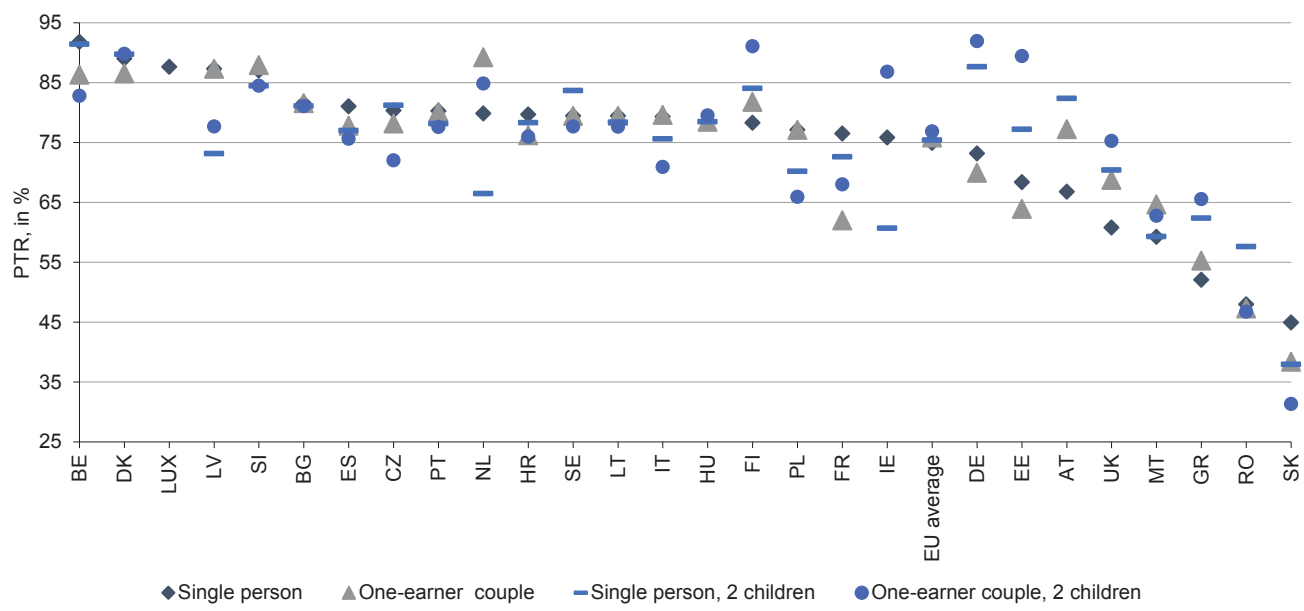

Notes:

- Countries are ranked by decreasing value of the PTR for single person with no children.

- Data for Cyprus are not available.

- For definition of the PTR see Figure 1.

Sources: European Commission, 2018; OECD, 2018d; own calculations.

${ }^{13}$ Differences between the EU average and Slovenia are smaller at higher wages. For example, the EU average PTR was about 8-13 percentage points lower at the average wage and 2-7 percentage points lower at the 150 percent of the average wage in 2016 than in Slovenia across different family types (European Commission, 2018). 
The majority of the PTR for unemployment in Slovenia is attributable to the withdrawal of unemployment benefits. As can be seen in Figure 3(a), the PTR for a single person moving to employment at 67 percent of average wage results in 87.1 percent of increased earnings being lost - out of this reduction, 80 percentage points is due to withdrawal of unemployment benefits. The same is true for other family types. The PTR is lower for individuals and families taking a job at the average wage (implying that the loss of additional earnings when employed is lower), yet unemployment benefits present 59 percentage points of the total PTR, followed by the expenses for the social security ( 9 percentage points of the total PTR) (see Figure 3(b)). ${ }^{14}$

Unemployment benefits also present an important constituent of unemployment trap in other EU countries, followed by the income tax and social security contributions. In the United Kingdom, Ireland, Poland, the Czech Republic, Malta and Finland, a part of the additional income when taking a job is lost also due to withdrawal of housing benefits. In contrast, one-earner married couples in Denmark, Sweden and Slovenia, who transit to employment at 67 percent of average wage, still receive social assistance. Alternatively, some of the EU countries have introduced into-work or in-work benefits, which reduce the PTR and therefore increase the attractiveness of taking a job. For example, Slovakia records especially high into-work benefits, as they reduce PTR for 25 percentage points for single and one-earner couples with no children and two-earner couples, and for 32 percentage points for lone parents and one-earner families with two children ${ }^{15}$. In Romania, into-work benefits decrease the PTR for 8.6 percentage points (reduction is higher for two-earner couples, amounting 14.7 percentage points). Something similar can be observed for in-work benefits schemes: in Sweden, these policies reduce the PTR for 7.7 percentage points and in Finland for 6.4 percentage points..$^{16}$ As regards Belgium, France and the Netherlands, the in-work benefits reduce the PTR for 3.1 to 10.6 percentage points, depending on the type of a family (see European Commission, 2018).

Transition from unemployment to employment is even less financially attractive when the new job pays lower wage than the one earned before unemployment. As shown in Figure 4, if prior to unemployment a person receives 67 percent of the average wage and after the employment accepts a job with a lower wage (for example, at 50 percent of the average wage, which in Slovenia is equivalent to the minimum wage), a single person lost 96 percent of the increased earnings due to taxes and reduced unemployment benefits in 2016 (for comparison, the EU average amounted 86.8 percent). ${ }^{17}$ One- and two-earner couples with no children have lost even more than 100 percent of increased earnings. The reason for this lies in the fact that unemployment benefits are set as a percent of wage earned

\footnotetext{
${ }^{14}$ Employers in Slovenia are required to pay their workers travel allowance and meal allowance, which are not subject to taxation. Because unemployment benefit recipients do not receive these allowances, including this additional income, it reduces the unemployment trap in Slovenia by approximately ten percentage points (OECD, 2016).

${ }^{15}$ Data for transition to employment at 67 percent of average wage in 2016 (valid also for other countries).

${ }^{16}$ In both Sweden and Finland, reduction is the same across all family types.

${ }_{17}$ Similar estimates are observed if a person, earning average wage prior unemployment, re-employs at minimum wage or at 67 percent of average wage. If re-employing at the minimum wage in 2016, the PTR for single person was 102 percent, for lone parents with two children 87 percent, for one-earner family with no children 109 percent and with children 85 percent and for two-earner families with no children 111 percent and with children 99 percent (European Commission, 2018).
} 
Figure 3

Decomposition of the PTR for transition from unemployment to full-time employment at 67 percent of average wage (a) and at 100 percent of average wage (b), Slovenia, 2016, in percent

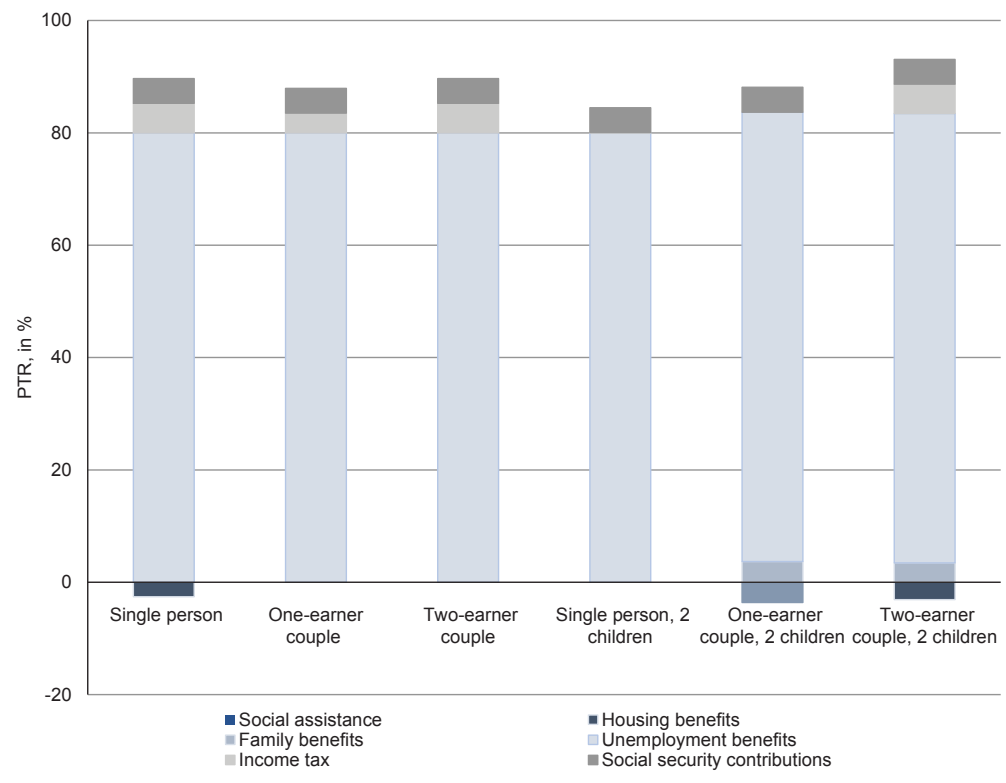

(a)

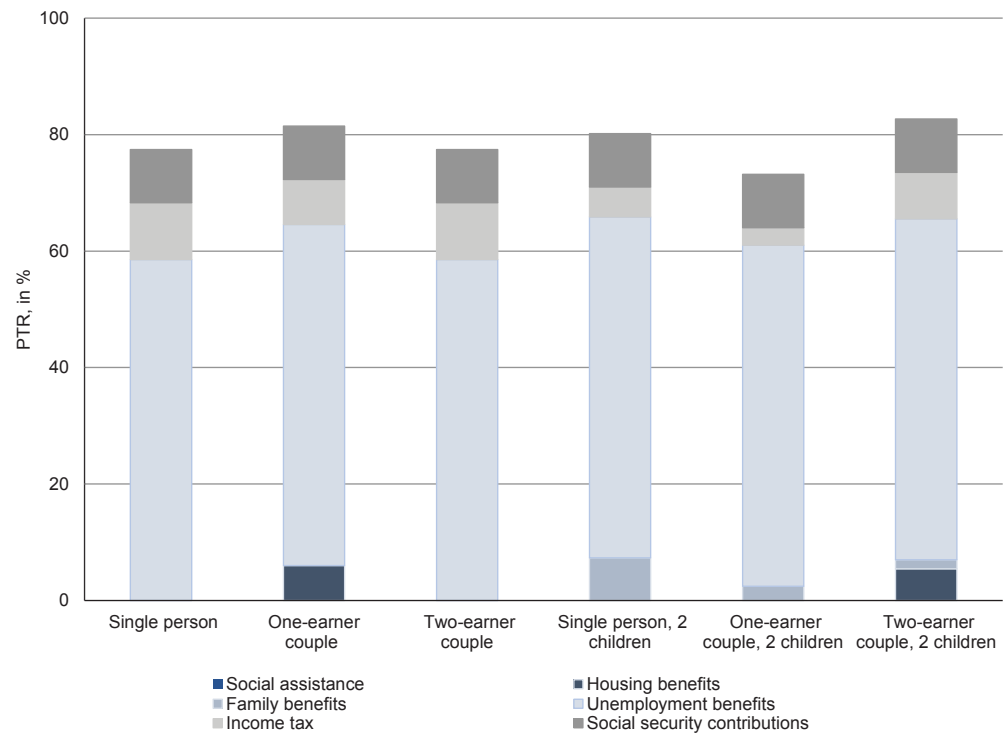

(b)

Note: For definition of the PTR see Figure 1.

Sources: European Commission, 2018; OECD, 2018d; own calculations. 
in the last employment (see Section 3). If moving to a higher paid job, the PTR rates are lower, although still high if compared to the EU countries - for example, if moving to employment at the average wage, a single person in Slovenia lost 74.2 percent of additional earnings in 2016, whereas the EU average was 62.4 percent (among the EU countries, PTR of single person was the lowest in Slovakia).

\section{Inactivity Trap}

Slovenia also faces strong inactivity traps, particularly for low-wage earners. ${ }^{18}$ For example, for lone parents and one-earner married couples (with or without children), 80 percent of increased earnings were lost when moving from inactivity to employment at the minimum wage in 2016 due to taxes and reduced financial social assistance. For

Figure 4

PTR when moving from unemployment to work at wage levels 50, 67 and 100 percent of average wage, with previous earnings of 67 percent of average earnings, Slovenia, 2016

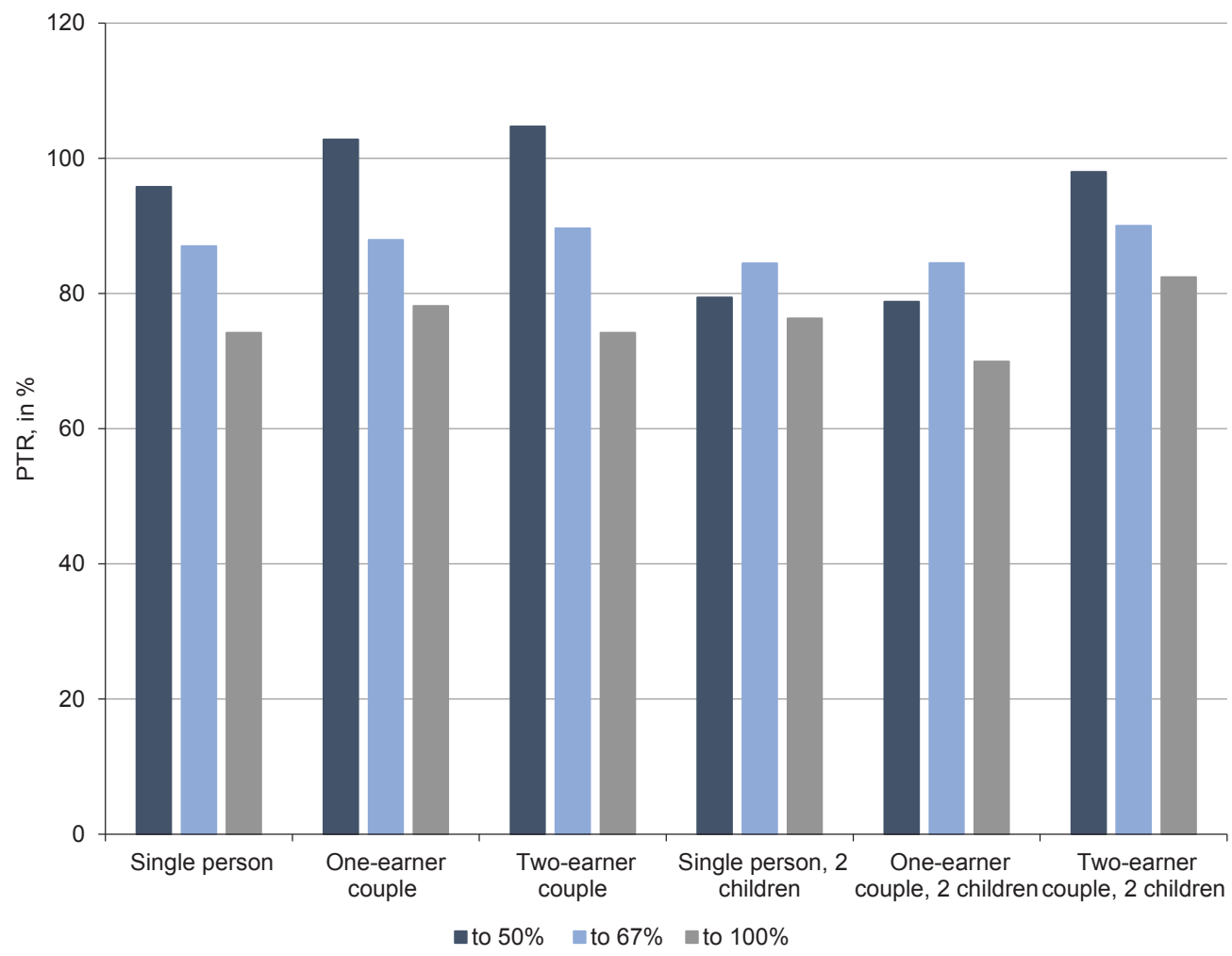

Note: For definition of the PTR see Figure 1.

Sources: European Commission, 2018; OECD, 2018d; own calculations.

${ }^{18}$ In this section we present the last available data for 2016. In 2018 the social assistance remarkably increased (see Section 3), implying that the inactivity traps are even higher. 
lone parents and one-earner families the PTR was even higher, reaching 85 percent when moving to employment at the 67 percent of average wage. At taking a job at the average wage, the PTR declined, however it still remained significant, as it ranged between 42 and 77 percent (see Figure 5).
Among the EU countries, Slovenia ranks in the upper half based on its inactivity trap (see Figure 6). ${ }^{19}$ Differences in the PTR when moving from inactivity to employment between the EU average and Slovenia are especially high for lone parents with two children (up to 32 percentage

Figure 5

PTR for transition into full-time employment for persons without entitlement to unemployment insurance but entitled to social assistance, Slovenia, 2016, in percent

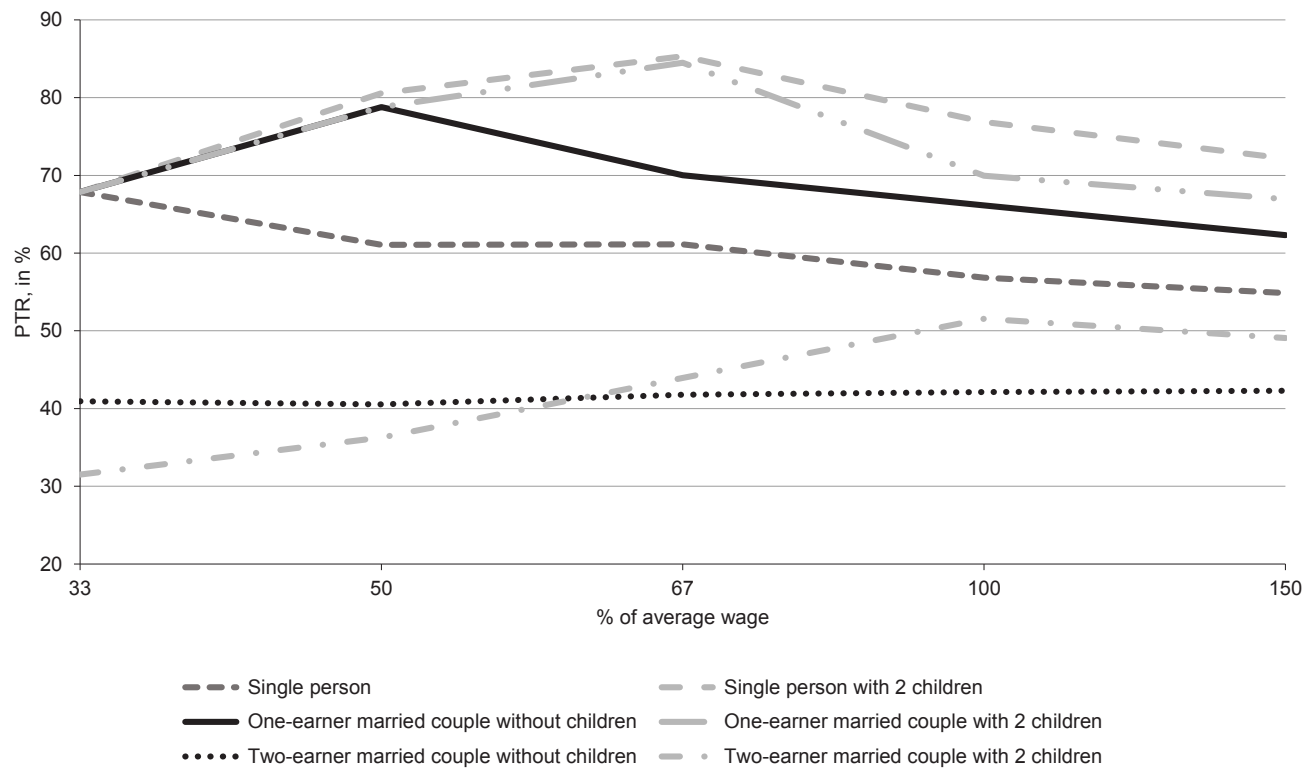

Notes:

The PTR relates to the situation of a person who is not entitled to unemployment benefit, but instead, he/ she receives social assistance and other means-tested benefits. Estimates are based on the following assumptions:

- The percentage of average wage relates to wage in full-time employment of the individual when moving into work. For married couples, the percentage of average wage relates to one spouse only; the second spouse is assumed to be inactive with no earnings in a one-earner married couple and to have full-time earnings equal to 67 percent of average wage in a two-earner couple.

- Estimates for families with children assume two children aged 4 and 6 and family benefits.

Sources: European Commission, 2018; OECD, 2018d; own calculations.

${ }^{19}$ With regard to the PTR for lone parents, Slovenia even ranks $1^{\text {st }}$ among the EU countries. 
points in case of employment at 67 percent of the average wage in 2016) and for one-earner married couples with children (11 and 19 percentage points in case of employment at minimum or at 67 percent of average wage, respectively). As shown in with two children, 85 percent of increased earnings were lost in 2016 when moving to employment at 67 percent of average wage - out of this reduction, 59 percentage points was due to the loss of financial social assistance, followed by 22 percentage points due

Figure 6

PTR for transition into full-time employment at 67 percent of average wage for persons without entitlement to unemployment insurance but entitled to social assistance, the OECD and the EU countries, 2016, in percent

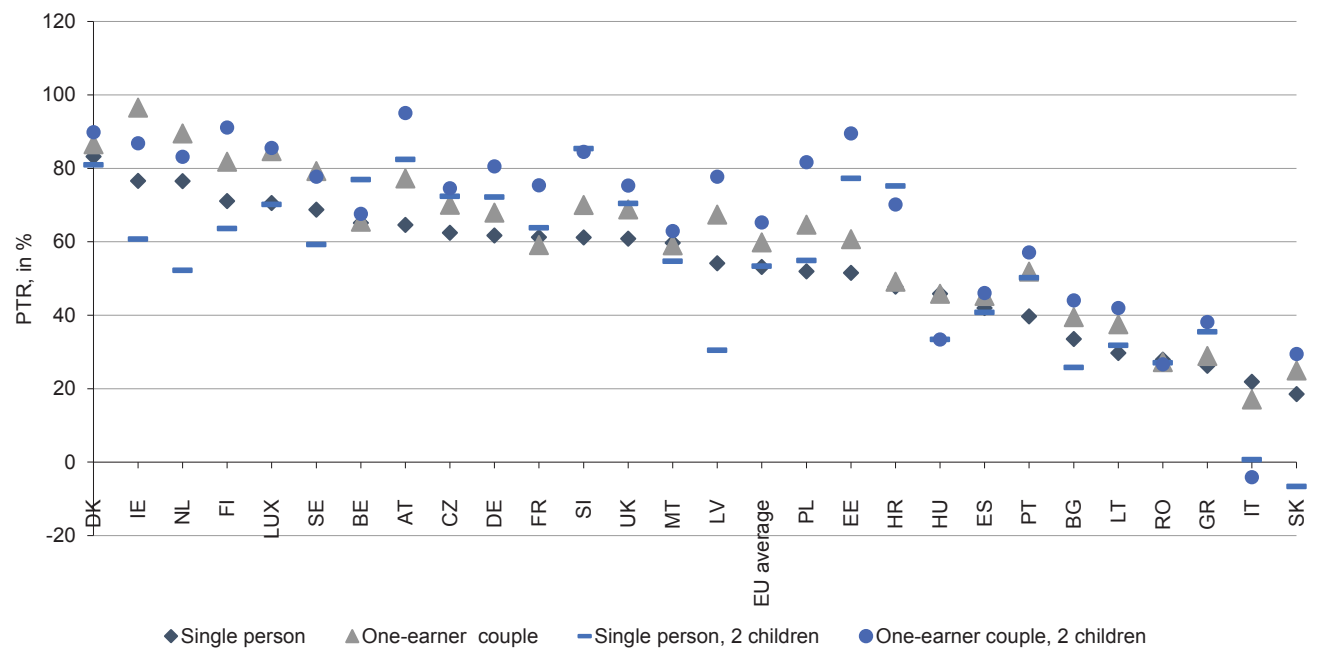

Notes:

- Countries are ranked by decreasing value of the PTR for single person with no children.

- Data for Cyprus are not available.

- For definition of the PTR see Figure 5.

Sources: European Commission, 2018; OECD, 2018d; own calculations.

Figure 6, when moving from inactivity to employment, workers lose the least in Slovakia - in 2016, the PTR amounted to 18.5 percent for a single person and 29.5 percent for one-earner families; for lone parents the PTR is even negative.

In Slovenia, as in the majority of the EU countries, the major component of the inactivity trap is the loss of financial social assistance. In the case of a one-earner family to payment of social security contributions (see Figure 7(a)). Financial social assistance is an important constituent of the inactivity trap also for one-earner couples with no children and lone parents (see Figure 7(a)). When moving to employment that pays a larger wage, the inactivity trap lowers (see Figure 7(b)) for the case of moving to employment at average wage). 
Figure 7

Decomposition of the PTR for transition from inactivity to full-time employment at 67 percent of average wage (a) and at 100 percent of average wage (b), Slovenia, 2016, in percent

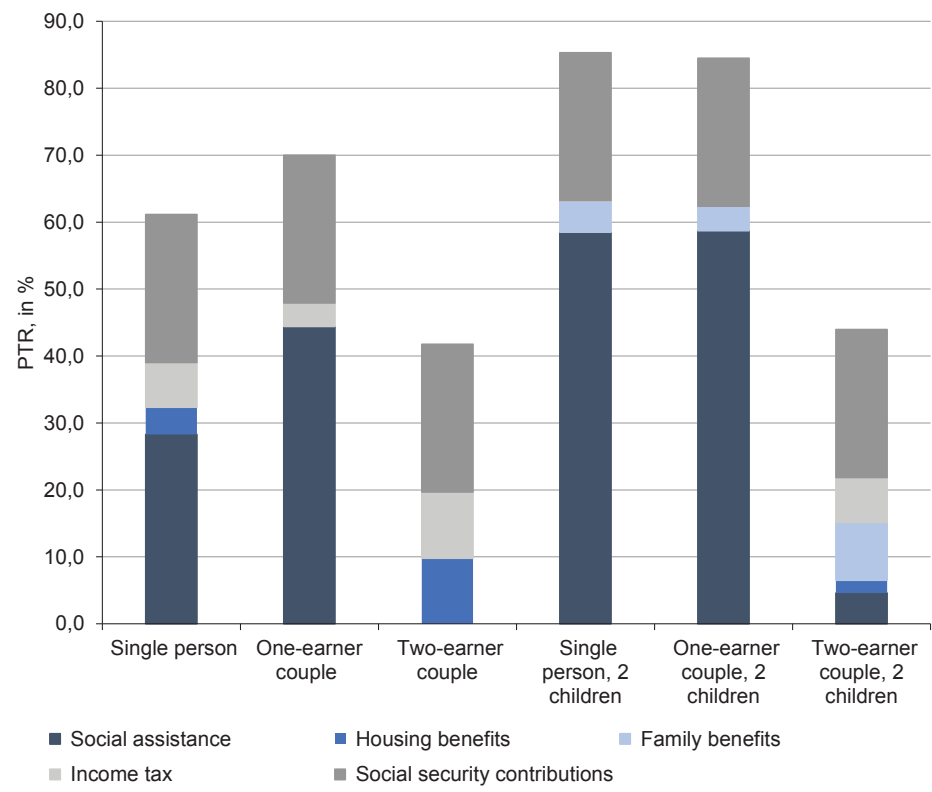

(a)

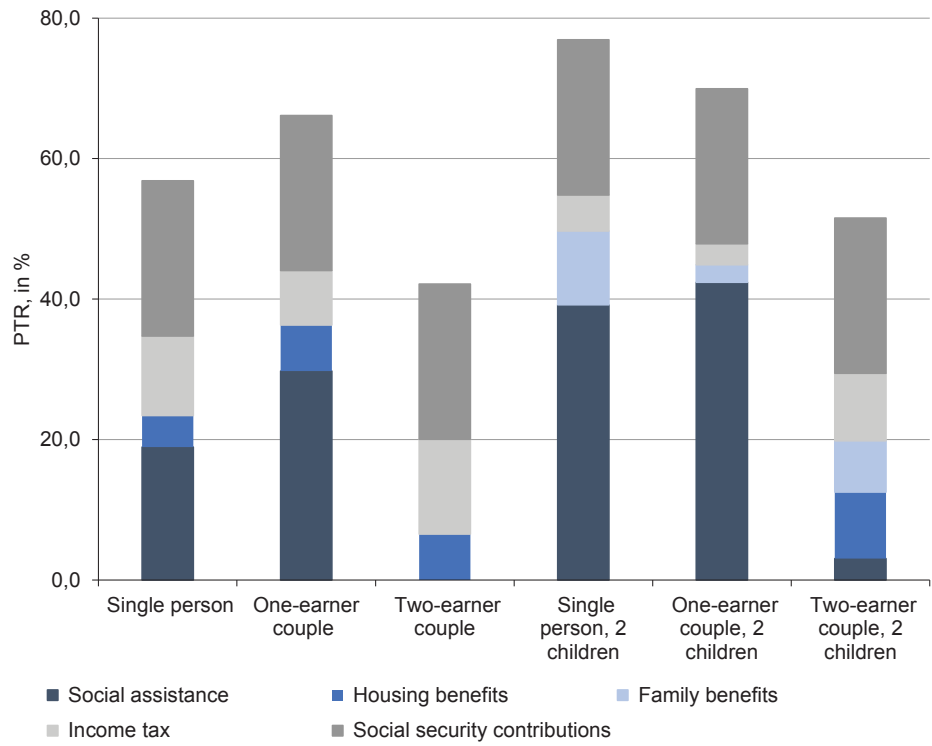

(b)

Note: For definition of the PTR see Figure 5.

Sources: European Commission, 2018; OECD, 2018d; own calculations. 
The EU countries with the highest inactivity traps are the Scandinavian and Western European countries, while the lowest ones are Romania, Greece, Italy and Slovakia - as already shown in Figure 6, in all these countries PTRs were below 40 percent for all family types in 2016. Some EU countries reduce their rather high inactivity traps by introducing in-work or into-work benefits - in Ireland, in-work benefits reduced the inactivity trap for one-earner families and lone parents with two children by 23 percentage points in 2016 . In Slovakia, which has temporary into-work benefit and records the lowest inactivity traps, this reduction was even higher, ranging from 20.7 percentage points for single persons and one-earner couples without children to 41.4 percentage points for two-earner couples (European Commission, 2018). ${ }^{20}$

\section{Low-wage or Poverty Trap}

The low-wage trap in Slovenia is especially high for families with children. The low-wage trap or METR measures the extent to which taxes and benefits reduce the financial gain of increasing work hours. As shown in Figure 8, in 2016 the tax burden, when increasing working hours (for example, from 33 to 67 percent of a full time job) for a one-earner married couple with two children was 80 percent, while it was 72 percent for a lone parent with two children. Compared to the EU average, the
METR in Slovenia is up to 26 percentage points higher for lone parents, whereas for one-earner families 23 percentage points (European Commission, 2018). Moreover, Slovenia ranks second among the EU countries by METR for married couples with two children and working spouse earning 67 percent of average wage - in 2016, the METR for moving from 67 percent to fulltime job amounted to 59 percent, implying that this percentage of increased earnings was lost due to higher taxes and social security contributions and reduced social transfers. By contrast, the comparable EU average in 2016 was 40 percent (see European Commission, 2018). A closer analysis of EU countries shows that the lowest METR was recorded for families in Bulgaria, Estonia, Lithuania and Croatia.

The tax burden of moving to a higher paid job reflects the higher income taxes and social contributions in the higher paid job, and in some family types also loss of social assistance. As shown in Figure 9, almost the entire low wage trap for individuals and families with children when moving from 33 to 67 percent of a full time job is attributable to the increased tax burden (higher income tax and social security contributions). An exception to this rule are lone parents and one-earner couples with two children, where more than half of the loss of additional earnings when moving to higher paid job is attributable to the loss of social transfers.

\footnotetext{
${ }^{20}$ The inactivity traps in Slovenia are probably lower, as they do not include travel and meal allowance and reduction of childcare benefits due to transition in employment (OECD, 2016).
} 
Figure 8

METR for part-time employees at different working-hours transitions, Slovenia, 2016, in percent
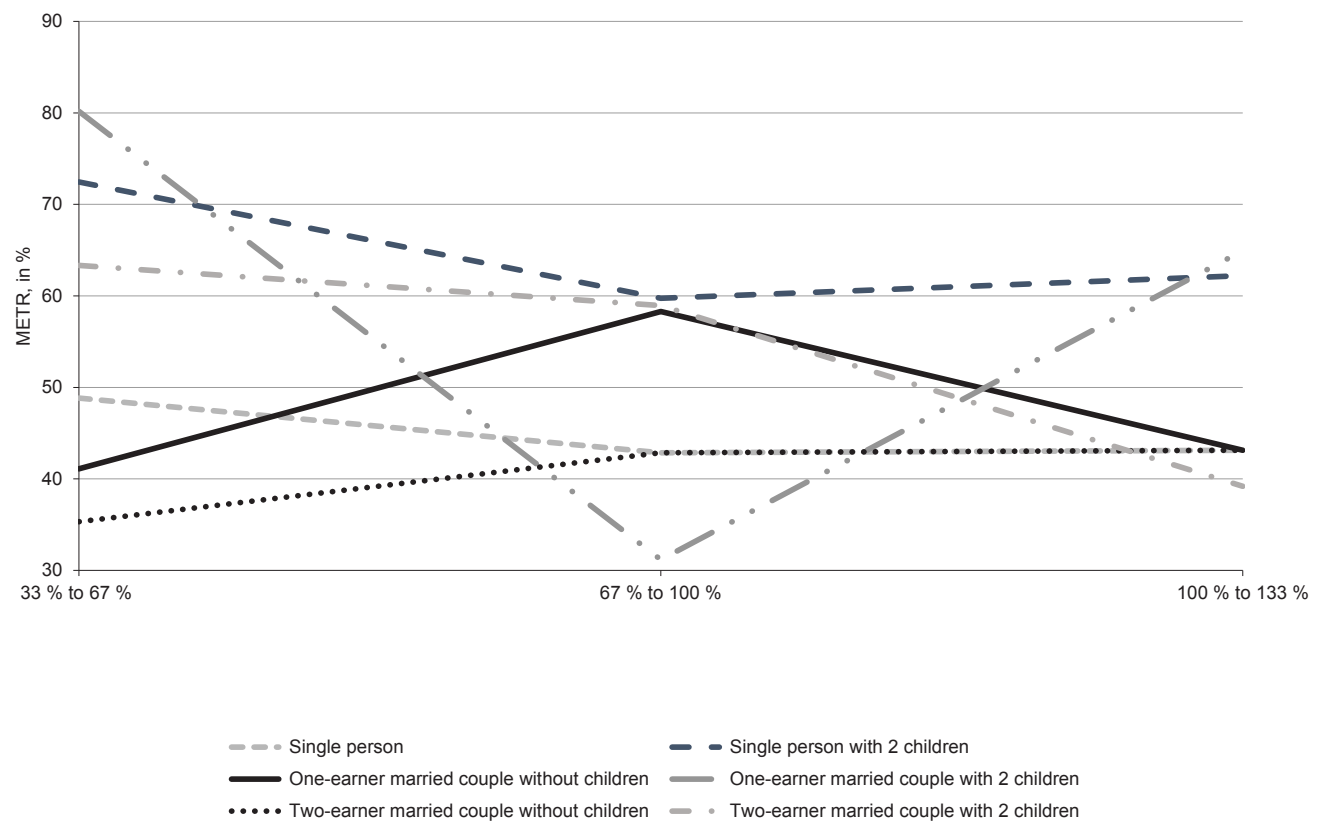

Notes:

- Hourly earnings correspond to the average wage level throughout so that a $1 / 3$-time employee would have earnings equal to 33 percent of average wage.

- Means-tested benefits, including cash housing assistance, are assumed to be available subject to the relevant income conditions.

- Children are aged 4 and 6; family benefits are included

- For married couples the percentage of average wage relates to one spouse only; the second spouse is assumed be "inactive" with no earnings in a one-earner married couple and to have full-time earnings equal to 67 percent of average wage in a two-earner couple. In the case of the one-earner married couple, where receipt of social assistance or other minimum-income benefits is subject to activity tests (such as active job-search or being "available" for work), these requirements are assumed to be met by the second spouse.

Sources: European Commission, 2018; OECD, 2018d; own calculations. 
Figure 9

Decomposition of the METR for moving to higher paid job (from 33 to 67 percent of average wage), Slovenia, 2016, in percent

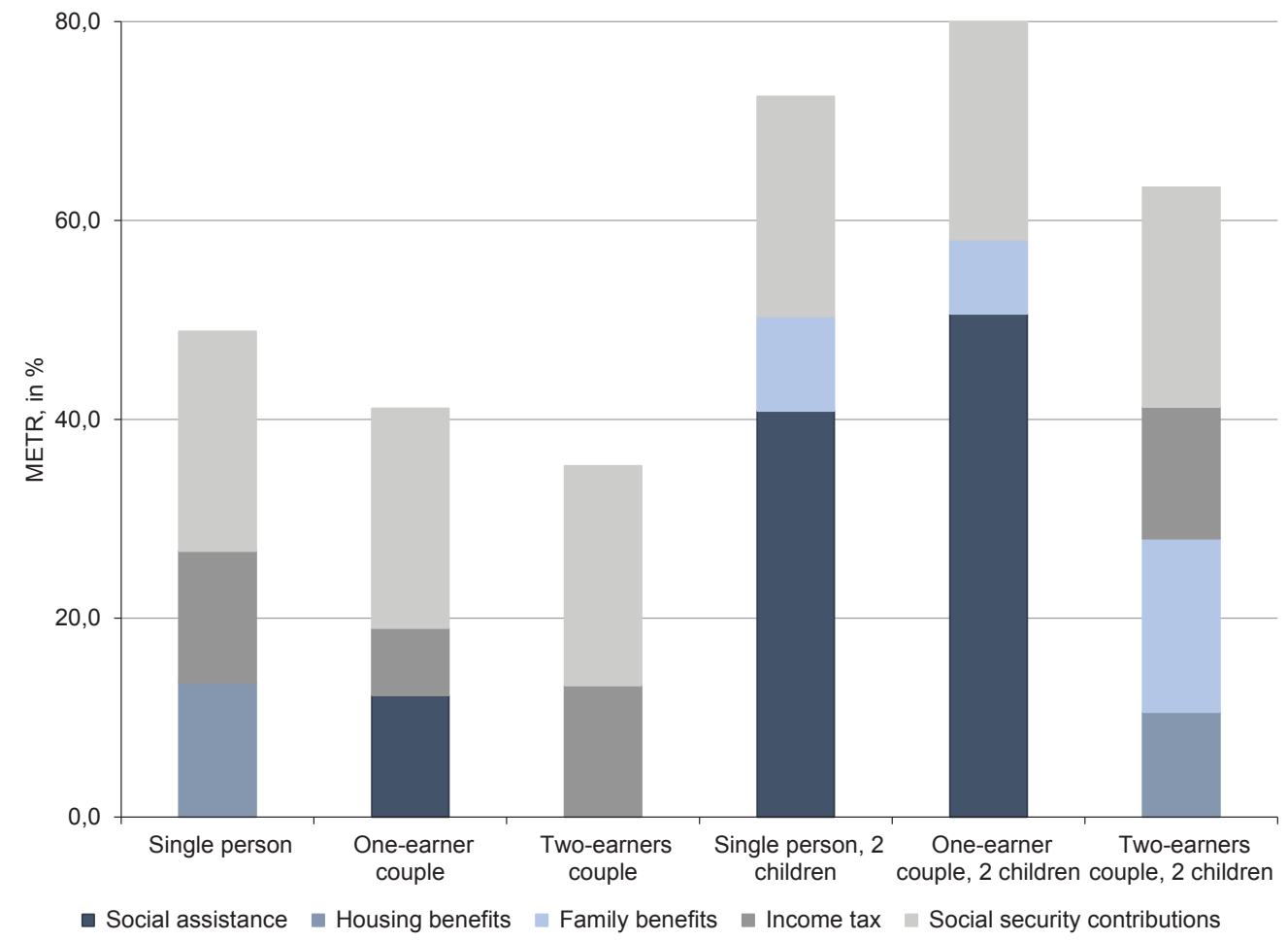

Note: Definition of the METR is available at Figure 8.

Sources: European Commission, 2018; OECD, 2018d; own calculations.

In the EU perspective, Slovenia also has relatively high low-wage traps for individuals and families without children. The METR for transition from 33 to 67 percent of a full-time job or from $2 / 3$ to a full-time job for single persons and two-earner couples in Slovenia is above the EU average. For example, for single person who moves from $2 / 3$ to a full-time job the METR amounted 42.8 percent in 2016, whereas the EU average was 39.3 percent; the difference is higher in case of one-earner couples - the METR in Slovenia amounted 58.3 percent in 2016, the EU average was 39.1 percent.
Overall, low-wage traps for individuals and families with no children are the highest in Scandinavian and Western European countries. In contrast, the low-wage trap is rather low in Slovakia, Bulgaria and some Baltic countries (European Commission, 2018).

\section{CONCLUSIONS AND DISCUSSION}

Making-work-pay policies allow for pursuing income redistribution and poverty reduction goals while simultaneously improving work incentives and promoting 
transitions to employment, which is clearly a social welfare maximizing strategy. This is one of the reasons why a growing number of OECD countries has already introduced one of the two forms of making-work-pay policies: into-work benefits and in-work benefits.

From our analysis above it is clear that in Slovenia families and individuals who are not working have poor incentives to find a job - because for many, "it does not pay to work." In other words, unemployment benefits and cash transfers, coupled with high tax wedge, may have a strong effect on work disincentives in Slovenia. Our main findings are:

- Financial incentives to move from unemployment to employment in Slovenia are among the weakest in the EU, regardless the family type or wage level.

- Transition from unemployment to employment is financially particularly unattractive when the new job pays a lower wage than earned before unemployment - in such cases, the transition to work may even reduce the net income.

- Slovenia records high inactivity traps, particularly for low-earning lone parents and one-earner married couples with children, placing it in the upper half among the EU countries ranked by the level of disincentives.

- Poverty traps in Slovenia are close to the EU average, but for two-earners married couples with children, Slovenia is at the very top.

However, work disincentives are not influenced only by financial factors, but there are also other important factors which influence labor market participation and which were not studied in this paper. For exam- ple, better working conditions, possibility for promotion, development and training, and stimulating work environment, i.e., factors that should be addressed by employers are providing decent payment. Important non-financial factors also include the availability of childcare and balance between work and family life (EMCO, 2003).

Given the above evidence, Slovenia should consider introducing into-work benefits, in-work benefits, or both. While presently such policies are virtually non-existent, they undoubtedly provide a much more attractive and ultimately viable option in comparison to cutting welfare benefit levels - an alternative strategy to enhance currently weak financial incentives to work. ${ }^{21}$ In the light of international experience with such policies and given the strong work disincentive created by unemployment, inactivity, and low-pay traps, in Slovenia such policies have a great potential to stimulate transitions from non-employment to employment. They would particularly help vulnerable groups, such as long-term benefit recipients and low-paid workers, but also older workers and young mothers. By increasing employment participation, such policies are also likely to contribute to a more equal income distribution, as well as to a reduction of in-work poverty. Such developments were, for example, observed both in France and in the United Kingdom, where in-work benefits increased the household incomes and reduced poverty rates (see, for example, Canova, Piccoli and Spadaro (2015) for France, and OECD (2014) and Browne, Hood and Joyce (2016) for the United Kingdom). The German Hartz reform was also effective in increasing employment and helping the long-term unemployed in finding more stable post-unemployment jobs,

\footnotetext{
${ }^{21}$ The only exception is rather low activity allowance (with a maximum of 200.12 EUR) paid to the recipients of financial social assistance when taking a part-time job or voluntary work, however it presents a weak incentive to progress to full-time employment.
} 
but by generating mostly low paid employment, its effect on poverty was limited (see, for example, Galassi (2016)).

In designing into-work benefits, Slovenia may be following the examples of Austria, Romania or Slovakia. In these countries, into-work benefits are targeted to persons taking employment on a fulltime basis. ${ }^{22}$ Particular attention should be given to reducing deadweight losses, that is, to minimizing the likelihood that beneficiaries would have found a job even in the absence of the benefit scheme (OECD, 2018d). ${ }^{23}$ This can be achieved by narrowing the entitlement to vulnerable groups, such as the long-term unemployed, unemployed with low-earnings capacity, and older unemployed. One modality of into-work benefits is to pay out unemployment benefits, at a reduced rate, for the remainder of potential duration, as an into-work benefit (as practiced in Japan and Korea, for example). By doing so, Slovenia would also reduce the moral hazard problem plaguing the behaviour of unemployment benefit recipients - the fact that the receipt of unemployment benefits reduces the likelihood of exiting unemployment (see Vodopivec et al., 2015). Another good side of into-work benefits is relatively low budgetary costs. On the other hand, the drawback of into-work benefits, as mentioned above, is the fact that their employment effects decline or fade near the point of the exhaustion of bene- fits, as well as that (because they are mostly linked to individuals) they have limited effects on families with dependent children. Furthermore, as they are time-limited, there is a risk that workers do not progress to the stage of earning a self-sufficient wage. Their income redistribution and poverty reduction impact is limited, too.

Another approach to stimulate work incentives - addressing some of the shortcomings of into-work benefits - is via inwork benefits. Above all, in-work benefits are provided on a permanent basis and, as such, are a more effective tool in stimulating work incentives. In-work benefits can be either individual or family-based. Although family based in-work incentives can result in higher redistribution effects, they can also create work disincentives, especially for second-earners. Possible drawbacks of in-work benefits are that they may create low-wage traps and fail to encourage workers to develop their skills. ${ }^{24}$ Nevertheless, in-work benefits schemes are rather expensive - with costs reported up to 2 percent of the GDP (OECD, 2014) - and administratively demanding. ${ }^{25}$ Therefore, a special attention should be given to the reduction of deadweight losses. This can be achieved by well-designed targeting and phasing-out rates - set at low levels if the main objective is to incentivize workers to employ or at higher levels if the main concern is keeping workers in jobs. ${ }^{26}$

\footnotetext{
${ }^{22}$ Applying the full-time employment condition may limit the job possibilities for persons welfare, who can only take part-time jobs (OECD, 2005).

${ }^{23}$ Part of this cost is outweighed through the increased employment.

${ }^{24}$ As benefits are paid out as long as wages are below set threshold, workers would not raise their working hours or work effort or increase their skill in order to still qualify for the benefit - this is especially the case if benefits are generous or difficult to access (see Section 3; OECD, 2003).

${ }^{25}$ Immervoll (2016) points on the trade-off between the cost of in-work benefits and their effects - either in-work benefits are costly or damage work incentives.

${ }^{26}$ Targeting can help reduce costs in two ways: (i) directly, by reducing the number of indented beneficiaries; and (ii) reducing the number of windfall beneficiaries (OECD 2005). Yet, it should be kept in mind that if targeting is to narrow it can have limited effects, affect behavior of welfare recipients and raise questions about equity (OECD, 2003, 2005).
} 
Of course, the complexity of the design of making-work-pay policies - and the demands they pose on their administration - should not be underestimated. How hard getting the design right can be maybe gauged from the case of the United Kingdom: even in a country that has substantial experience with such policies, the overhaul of its making-work-pay policies has undergone significant changes and it will take more than a decade to be achieved. The complexity arises because it is necessary to view these policies not in isolation, but rather as a component of a comprehensive strategy to help the transition from welfare to work (OECD, 2005; Immervoll and Pearson, 2009). Other elements that should be considered are family allowances, childcare subsidies, particularly for single parents, and other fringe benefits (above all in Slovenia, reimbursement of travel costs and meals). ${ }^{27}$ Another important element to be considered is the existence of minimum wage - appropriately set minimum wage is one way to ensure that workers, and not their employers, benefit from in-work benefits. Moreover, as the case of Germany shows, effective changes in activation policies are also an important ingredient of welfare to work reforms.

Designing a system where strong work incentives are compatible with a country's social policy goals can be difficult. It involves balancing the desire to protect the most vulnerable members of society - for example, families with children - while maintaining incentives for individuals to engage in productive work. Countries with strong social policies, such as Slovenia, are arguably quite successful in achieving the former. To be successful at the latter, into- or in-work benefits arguably have an important role - and it should be kept in mind that they create a large, meaningful impact only if they create a sizeable difference between welfare out-of-work and work income, if they are well targeted to a specific income groups or family types and are not excessively bureaucratic.

\section{BIBLIOGRAPHY}

Bargain, O. (2008). Making work pay - Assistance to low-paid workers in Europe. Research Note 2/2008. European Observatory on the Social Situation and Demography.

Bargain, O., Caliendo, M., Haan, P., \& Orsini. K. (2010). Making work pay in a rationed labour market. Journal of Population Economics, 23(1), 323-351. https://doi.org/10.1007/s00148008-0220-9

Browne, J., Hood, A., \& Joyce, R. (2016). The (changing) effects of universal credit. In C. Emmerson, P. Johnson, \& R. Joyce (Eds.), The IFS Green Budget Report 2016 (pp. 232-259). London: IFS. Available at https://www.ifs.org.uk/uploads/gb/ gb2016/gb2016.pdf

Canova, L., Piccoli, L., \& Spadaro, A. (2015). An ex ante evaluation of the Revenu de Solidarité Active by micro-macro simulation techniques. IZA Journal of European Labor Studies, 4(17). https://doi.org/10.1186/s40174-015-0040-3

Carone, G., Immervoll, H., Paturot, D., \& Salomäki, A. (2004). Indicators of unemployment and lowwage traps (Marginal effective tax rates on employment incomes). OECD Social, Employment and Migration Working Paper 18. Paris: OECD.

Dolenc, P., \& Laporšek, S. (2010). Tax wedge on labour and its effect on employment growth in the European Union. Prague Economic Papers, 19(4), 344-358. https://doi.org/10.18267/j.pep.381

Edwards, C., \& de Rugy, V. (2015). Earned income tax credit: Small benefits, large costs. Available at https://www.downsizing government.org/ earned-income-tax-credit

\footnotetext{
${ }^{27}$ By taking a job, the cost of childcare significantly increases, which might further disincentive individuals, especially mothers, to move from non-employment. An option to address this issue is introduction of childcare subsidies, which according to studies for the Unites States had important effect on transition of women to employment (for an overview of studies see OECD, 2005).
} 
Employment Committee. (2003). Making work pay. Facts, figures and policy options. Report to the Employment Committee. Available at http://ec.europa.eu/social/BlobServlet?docId $=2530$ \&langId=en

Employment Service of Slovenia. (2018). Denarno nadomestilo (Unemployment Insurance). Available at http://www.ess.gov.si/iskalci_zaposlitve/ prijava_brezposelne_osebe/ denarno_nadomestilo

European Commission. (2015). Tax and benefits indicators database: indicator definitions. Available at http://ec.europa.eu/economy_finance/ db_indicators/tax_benefits_indicato rs/definitions_en.htm

European Commission. (2018). Tax and Benefits Indicators Database. Available at http://ec.europa. eu/economy_finance/db_indicators/tab/

Galassi, G. (2016). The German mini-job reform: Intended and unintended consequences. European University Institute. Available at https://editorialexpress.com/cgi-bin/conference/download. cgi?db_name=EEAESEM2016\&paper_id $=2474$

Gerbery, D. (2015). ESPN Thematic Report on Social Investment - Slovakia. Brussels: Directorate-General for Employment, Social Affairs and Inclusion. Available at http://ec.europa.eu/social/ BlobServlet?docId=13858\&langId=en

Immervoll,H. (2016). Supporting low-earning workers: Trends and challenges. Social Situation Monitor, Seminar "Making Work Pay", Brussels, 25th May 2016.

Immervoll, H., \& Pearson, M. (2009). A good time for making work pay? Taking stock of in-work benefits and related measures across the OECD. IZA Policy Paper No. 3. Bonn: Institute for the Study of Labor (IZA).

Labour Market Regulation Act. Official Gazette of the Republic of Slovenia, No. 80/2010, 21/2013, 63/2013, 100/2013.

Matsaganis, M., \& Figari, F. (2016). Making work pay. A conceptual paper. Research note 3/2016. Brussels: Directorate-General for Employment, Social Affairs and Inclusion. Available at http://ec.europa.eu/social/BlobServlet?do$\mathrm{cId}=16330$ \&langId=en

Ministry of Labour, Family, Social Affairs and Equal Opportunities of the Republic of Slovenia. (2019). Financial Social Assistance. Available at http:// mddsz.arhiv-spletisc.gov.si/en/areas_of_work/ social_affairs/financial_social_assistance/

Organisation for Economic Co-operation and Development. (2003). OECD Employment Outlook 2003. Paris: OECD.

Organisation for Economic Co-operation and Development. (2004). Taxing Wages 2002/2003. Paris: OECD.

Organisation for Economic Co-operation and Development. (2005). OECD Employment Outlook 2005. Paris: OECD.

Organisation for Economic Co-operation and Development. (2014). Connecting people with jobs. Activation policies in the United Kingdom. Paris: OECD.

Organisation for Economic Co-operation and Development. (2016). Connecting people with jobs. The labour market, activation policies and disadvantaged workers in Slovenia. Paris: OECD.

Organisation for Economic Co-operation and Development. (2018a). Benefits and wages: Country policy descriptions. Available at http://www. oecd.org/els/soc/benefits-and-wages-country-specific-information.htm

Organisation for Economic Co-operation and Development. (2018b). Tax and Benefit Systems: OECD Indicators. Available at http://www.oecd. org/social/benefits-and-wages.htm

Organisation for Economic Co-operation and Development. (2018c). Methodology. Available at http://www.oecd.org/els/soc/Methodology.pdf

Organisation for Economic Co-operation and Development. (2018d). Benefits and wages: Tax-Benefit Calculator. Available at http://www.oecd.org/els/ soc/benefitsandwagestax-benefitcalculator.htm

Organisation for Economic Co-operation and Development. (2019). OECD Statistical Database. Available at http://stats.oecd.org/

Van der Linden, B. (2016). Do in-work benefits work for low-skilled workers?. IZA World of Labor. Available at http://wol.iza.org/articles/ do-in-work-benefits-work-for-low-skilled-workers-1.pdf

Vodopivec, M., Laporšek, S., Dolenc, P., \& Vodopivec, M. (2015). The effect of unemployment benefit generosity on unemployment duration: Quasi-experimental evidence from Slovenia. IZA Discussion Paper 9548. Bonn: Institute for the Study of Labor (IZA). 


\title{
Sažetak
}

\section{POLITIKA ISPLATIVOSTI RADA U SLOVENIJI}

\section{Suzana Laporšek, Milan Vodopivec, Matija Vodopivec}

Fakulteta za management, Univerza na Primorskem

\author{
Koper, Slovenija
}

Članak analizira poticaje za prijelaz iz nezaposlenosti u zaposlenost izražene pomoću različitih financijskih pokazatelja u Sloveniji i uspoređuje ih s onima u državama EU. Članak daje pregled glavnih značajki politika isplativosti rada i raspravlja razloge za njihovu primjenu u Sloveniji. Pokazuje se da u Sloveniji obitelji i pojedinci koji ne rade imaju slabe poticaje za pronalaženje posla, jer za mnoge se „posao ne isplati“. Naknade za nezaposlene i novčane naknade, zajedno s visokim poreznim klinom, odvraćaju od rada. Kako bi se riješio ovaj problem, Slovenija bi trebala razmotriti uvođenje dodataka za zapošljavanje, naknada za zaposlene ili oboje. Trenutačno takve politike gotovo ne postoje. U svjetlu međunarodnih uspješnih iskustava s takvim politikama is obzirom na visoki destimulirajući učinak koji stvaraju zamke nezaposlenosti, neaktivnosti i niskih plaća, takve politike u Sloveniji imaju veliki potencijal za poticanje prijelaza iz nezaposlenosti u zaposlenost $i$ ostanak u radnom odnosu.

Ključne riječi: politika isplativosti rada, naknade za zaposlene, dodaci za zapošljavanje, zamla nezaposlenosti, zamka neaktivnosti, zamka niskih plaća, Slovenija. 